\title{
FROM WORLD HERITAGE TO ENVIRONMENTAL PATRIMONY
}

\author{
A. Duț-Buzura
}

\author{
Andrei Duțu-Buzura \\ Faculty of Law, \\ Ecological University of Bucharest, Bucharest, Romania \\ *Correspondence: Andrei Duțu-Buzura, 1G Vasile Milea Blv., Sector 6, Bucharest, Romania \\ E-mail: contact@andreidutu.net
}

\begin{abstract}
Environmental law has proven itself to be a major challenge to all traditional branches of law, given its "horizontal" perspective and functioning, by encompassing elements and institutions from almost all of them, and by offering new insights and approaches to long consecrated concepts and juridical mechanisms.

The relation between civil law, one of the oldest fields of regulation of any legal system, and environmental law, a creation of the late XXth century, have proven itself to be not only intriguing and original, but also necessary, in view of the creation of the juridical structures fit to face the imperatives of the social, scientific and economic developments currently in course. By interfering with elementary concepts, such as property right and patrimony, environmental law has brought up the opportunity of creating new juridical theoretical structures, corresponding to the actual necessities of the beginning of the XXIst century.

This paper proposes construct following these lines, the environmental patrimony, having as theoretical models both the concept of patrimony, consecrated by civil law, and common or natural heritage, as accepted in international law. As practical aspects, we turned to the environmental protection mechanisms already in existence, thus to give a more complete and functional structure as possible.
\end{abstract}

Keywords: environment, patrimony, property right, absolute, limitations, owner, titular, holder, heritage, nature, international, pollution, domain, tradition, innovation, civil regime, environmental regime, science.

Introduction. Property, patrimony, heritage.

Despite the absolute character, unanimously accepted, of the property right, as it has been consecrated by the elementary regulations of any civil code legal system, all along the second half of the XXth century, thee limitations and the restrictions imposed upon it have exponentially grown, apparently depriving the owner of numerous prerogatives regarding his own goods. A great deal of these limitations have their origins in regulations regarding environmental protection; in this sense, a good example resides in the Romanian Constitution of 1991, at article 44 paragraph 7, as revised in 2003, which states that "the property right obliges to the respect of the encumbrances related to environmental protection and assuring good neighborhood, and also to the respect the other encumbrances which, according to law or custom, are charged to the owner.

From the contents of these provisions, it ensures that preset regulations pertinent both to environmental and urbanism law have a significant role in the limitation of the aforementioned prerogatives, on the purpose of assuring a common objective which, according to the law maker, justifies all the detriments to the property right. As long as there are accepted "limitations" and/or "restrictions" of any nature, we appreciate that they do not actually interfere with the base nature of the property right. 


\section{A. Duțu-Buzura}

In an opinion present in the French jurisprudence ${ }^{1}$, property is the right in virtue of which a person may profit from a certain good, in a sense of obtaining all possible benefits from it, and the encumbrances imposed by law do not interfere at all with the "empire" of property. Thus, according to the principle of sovereignty, it does not have to be confirmed at every moment, by an evident manifestation of its absolute character.

Related to the exclusive character of the owner's prerogatives, another case law opinion $^{2}$, supporting a similar approach, states that the limits to the property right are exclusively external and do not influence the essence of the right, but only some prerogatives related to use. According to the same opinion, the external encumbrances do not affect the exclusive status of property, because they do not imply mixing in the relation between the owner and their good. We consider that such an explanation would gain even more pertinence given that such forms of common property, collective property, indivisible property, the right of superficies, land rent etc. are to be taken into account.

A regulation of major importance, both practically and theoretically, deemed to be mention within this paper, is the French Charte de l'environnement (Environmental Charter) of April 28th, 2005, a regulation of constitutional status that provides, among others, that "environment is a common patrimony of the nation". However, such a statement is not quite new to French law, give that it states once more what was previously provided by article $\mathrm{L}$ 110-1 of the Code de l'environnement (Code of the Environment) regarding the common patrimony of the nation, its elements being "spaces, resources and natural environments, sites and landscapes, air quality, animal and vegetal species, biologic diversity and balances to which they contribute", but also water, according to article L 220-1. Another French regulation, this time Le code de l'urbanisme (Code of urbanism), includes in the national patrimony "the entire French territory" (article L 110).

First consecrated within international law, knowing various forms and formulations, the concept of common patrimony/heritage has entered completely in the juridical world and can no longer be ignored ${ }^{3}$. Despite the official English terminology of "common heritage", we will opt for the term of "patrimony", to be able to emphasize more easily the connections with the concept of patrimony from private law, used mainly in civil law systems (see French "patrimoine" or Romanian "patrimoniu").

The doctrine has stated that "It is more and more evidently that certain forms of usage of lands can lead to their degradation, or even to their extinction. International ecology law and international economic law can do nothing but conjugate, for the future, in view of diminishing sovereignty that, at their best, proved to be inefficient, and at their worst, has proven their noxious nature" 4 . It is difficult to imagine, in such conditions, that forms of sovereignty thus "condemned" are limited to State sovereignty.

By re-organizing the relations between individuals and goods, as imposed by the technological al scientific evolution and the apparition of the global environmental phenomena, the concept of common patrimony/heritage propounds a re-analysis and rethinking of the relation between private and general interest, from a perspective that extends the historical studies of the jus-naturalists and leads to the recognition and acceptance, within the positive law, along with the sovereignty of the owner, asserting and accepting the prerogatives belonging to the collectivity, be it national, European or extended to the frontiers of humanity.

\footnotetext{
${ }^{1}$ Marquis de Vareilles-Sommières, La définition et la notion juridique de proprieté, RTD civ., 1905, p. 443.

${ }^{2} \mathrm{~T}$. Revet, Le Code civil et le régime des biens: questions pour un bicentenaire, rev. "Droit et patrimoine", mars 2004, p. 20.

${ }^{3}$ François Guy Trébulle, Environnement et droit des biens, vol. "Le droit et l'environnement", Tome XI/Caen, Dalloz, Paris, 2010, p. 85-115, 130.

${ }^{4}$ P. Juillard, Rapport français de droit international public, vol. "Travaux de l'Association Henri Capitant", La maitrise du sol, t. XLI, Economica, 1990, p. 189.
} 


\section{A new form of domain separation}

In the light of those presented up to this point, common heritage can be regarded from two points of view, on the one hand according to the individual and collective aspects, and on the other hand, from a "monist" perspective, according to the property law corresponding to the immovable goods. The limitations, especially the environmental ones, imposed upon the owner's prerogatives, are actually a reflection of the numerous interferences in their relationship with their goods; moreover, such conclusions make unacceptable the former, according to whom, beyond the limits of the absolutism of the exclusive character, (almost) anything is possible. In such conditions, the owner can follow his almost unlimited freedom to act within this exclusive space, without needing an authorization, and under any form this freedom can take. Instead, being a form of mastership specific to a collectivity, common heritage, without excluding the owner, imposes a true "co-property" over his elements, and can state, at least from this point of view, the end of exclusivism 5 .

Thus, this "new juridical environmental order" is looming pithier, "menacing" individual's ownership over certain goods, be they movable or immovable, but also having a specific character, be it cause of the necessity of their protection, be it in view of preventing and limiting the harms to the environment, and sharing it with the collectivity, as guardant of the application of the environmental measures.

It is to be observed that, in the context of regulations regarding common heritage, under its various forms, a secular return to the "universal" or "sacred" domain, a concept specific to European medieval law, identified by the theologians of the ages as belonging to the godhead ${ }^{6}$. Despite the fact that the writers of the French (Napoleon) civil code have excluded - no without some complaints - such an idea, this distinct domain of property has discretely appeared, under the auspices of international law. It bears upon the goods and confers to the collectivity a direct ownership over the ones that simultaneously fall under the regime of the universal domain or common heritage, but also under the private domain, the property right respectively ${ }^{7}$.

The issue of the revival of the "universal domain", a concept specific to a certain form of social and political organization, long gone, is not at all pertinent, given that it has been imposed in an age when restrictions to owner's prerogatives were limited, and they could be imposed solely by referring to the general interest, without mentioning the fact that the good could belong to more than one patrimony, and without a direct approach to the concerning good.

We consider that the most important input of environmental law, to this regard, resides in the fact that when it consecrate the less pertinent character of defending the owner's prerogative of disposition of the good, it brings forth the idea of abusus ${ }^{8}$, meaning the prerogative to dispose not solely legally, but also physically, of the good, in its materiality. Thus, it structurally menaces a specific attribute of the property right, the one that it is often considered as its most complete expression.

Environmental law forbids such a perception regarding property, specific to the juridical theory of the XIXth century; for instance, in a phrase of French professor Demolombe", "property confers to the master a sovereign power over their good, a total despotism", we find an ideology that has become outdated, obsolete, absolutely unacceptable

\footnotetext{
5 E. Zaccai, Générations futures, humanité, nature: difficultés des collectifs pour la protection de 'environnement, vol. "Le droit saisi par le collectif", Ed. Bruylant, Bruxelles, 2004, p. 275.

${ }^{6}$ M.-F. Renoux-Zagamé, Origines théologiques du concept moderne de propriété, Libraire Droz, Paris, 1987, p. $200,247$.

${ }^{7}$ Idem.

${ }^{8}$ Rémond Gouilloud, Le droit de détruire. Essay sur le droit de l'environnement, PUF, Paris, 1989, p. 27.

${ }^{9}$ Charles Demolombe, Cours de Code Napoléon, vol. IX, Paris, 1861, p. 462
} 


\section{A. Duţu-Buzura}

given the evolutions of the destructive powers of this "despot" that, most of the time, is proven to be far from enlightened ${ }^{10}$.

The restrictions imposed to the owner's prerogatives have acquired such an important nature, that they can no longer be considered exceptions. The notion of common patrimony imposes that, beyond the social function of property, it can be seen as the transposition of concurring mastery over a certain good, in the context of a new form of "universal domain".

The originality of the concept of common heritage/patrimony and, in the same time, the element that separates it from the private patrimony, in the form it has been analyzed by Aubry and Rau, resides in the fact that it detaches itself from the traditional liaison that patrimony has with the individual, its holder, to create a new link, to the collectivity. Thus it can confer to all its members a new individual right, recognized for every human being that "dismembers" the tradition property right ${ }^{11}$. The argument of the lack of juridical personality of this collectivity can be hereby rejected, given that the members themselves of this collectivity (citizens of a certain state, European citizens, all the human beings etc.) become holders of this common patrimony/heritage, of which they cannot be bereft. The institutional infrastructure implied in such a process, and also in creating a legal regime of protection, does not a priori involve the existence of a property right, such structures being solely managers or gerents of those goods.

Perceiving common heritage as a "domain" would lead to accepting an idea of returning to a socialized conception, a limited and, perhaps, a more utilitarian view upon the property right ${ }^{12}$. Obviously, it is not a return to the feudal order, nor a turning to socialism and/or communism, but it is important to notice that, following a new purpose and starting from the remarkable scientific progress, we find a qualitative division of the prerogatives regarding certain goods, thus allowing the observation and, eventually, the preservation of their "public" aspects.

Once the good has been integrated in many dominion regimes, the domain of property and the collective domain respectively, the juxtaposition of the credentials regarding a differentiate power may lead to a more strict respect of these diverse aspects and, moreover, of the plurality of its functions. In such conditions, using and disposing of the elements of common heritage are necessarily affected by their inclusion in one such patrimony, which makes the owner and also the collectivity that manages them, "guardians" of the good and a voucher of its diverse uses. Identifying the consequences of the existence of common heritages may also enrich case law, especially in aspects of administrative law.

Environmental law reveals, thus, an evolution of the structure of property law itself, towards a form of collective mastery, renouncing all forms of absolutist claims, be it private, collective or state.

\section{Property in its environment}

It is not necessary to recall that property right does not exist solely in regard of a certain good, but also in relation to other individuals or entities that, even though they are strangers to the relation between the owner and their good, are required to respect it. Because it implies complex relations between individuals and goods, environment cannot be fully comprehended but with regard to the concrete and extremely complex reality, where property right plays a most significant role. Thus, the concept of neighborhood comes forth as most essential.

\footnotetext{
${ }^{10}$ François Guy Trébulle, Environnement et droit des biens, vol. "Le droit et l'environnement", Tome XI/Caen, Dalloz, Paris, 2010, p. 85-115, 130

${ }^{11}$ G. Morin, Le sens de l'évolution contemporaine du droit de propriété, vol. "Le droit privé français au milieu du XXe siècle. Études offertes à G. Ripert", t. II, LGDJ, 1950, p. 15.

${ }^{12}$ E. Meynial, Notes sur la formation de la théorie du domaine divisée, vol. "Mélanges Fitting" II, Montpellier, 1908 , p. 419.
} 


\subsection{The notion of neighborhood}

It is well known, in the legal doctrine, that the first court decisions mentioning and consecrating the concept of "neighborhood troubles" have been pronounced in cases that we can appreciate, from our present perspective, as being among the precursors of the concept of the human right to a safe and healthy environment. Such an observation has its specific meaning, given that, as civil law has never been strictly independent or strange to the problem of the environment, it has been brought to the attention of the legal order precisely in questions regarding good neighborhood.

We must recall, in this context, an interesting remark, beyond its caricature aspects, that allows underlining certain essential aspects of our paper. Thus, French doctrine has concluded that "for the specialist in private law, environment means, first of all, neighborhood!"13 From an environmental perspective, such a statement reminds us that this notion has an essentially relative character, especially in its geographic aspects, because currently, it cannot be limited to the main meaning of the term, of spatial join or proximity. From this point of view, we can appreciate that modern neighborhood troubles, especially the ones related to pollution, redefine the frontiers of neighborhood according to the area of exposure of the trouble ${ }^{14}$. Be there sounds, stenches, or vibrations, and given the transboundary (or even global) character of pollution and its effects, neighborhood in itself will lose its initial meanings. Thus, in the present conditions, the distance implied by the concept of neighborhood becomes relative, surpassing the geographical limits of the immovable good in cause.

For instance, if the trouble is solely an aesthetic one, the limits of neighborhood may extend, surpassing an entire visual panorama. And if the trouble is linked to emissions of dangerous substances, chemical or radioactive, the boundaries of neighborhood extend to a planetary level.

Moreover, the assessment according to which "environment means neighborhood" allows emphasizing a multitude of such "neighborhoods". For a long time, as shown, this notion has not been comprehended but as a material neighboring, concrete, between two or more plots of land. Currently, also from a private law perspective, beyond this version, one must also consider personal neighboring, that unites individuals that are not necessarily connected to the concerning fields (immovable goods) by a property relationship ${ }^{15}$. For instance, a contractor, as an "occasional neighbor" can cause a trouble to the occupant (locator) of a neighboring apartment; in this situation, French case law has retained the existence of an abnormal trouble (Civ. 3e, 30 juin 1998, Bull. civ. III, no. 144; RDI 1998), even if none of the individuals concerned had been an actual owner. Such a plurality of the forms of neighborhood shows that it is a domain still to be explored. And yet, as it has been described by the doctrine since the beginning of the XIXth century, it allows us today to notice and solve the difficulties created by the coexistence of the interests between which a just balance is needed.

It seems to us that this notion, well anchored in the law of goods, allows the integration of the aspects regarding environmental protection. Such an integration is not, though, unlimited, and can raise a number of questions, especially regarding the means of repair, and if they can actually produce specific results.

4. The possibility of an environmental patrimony

If we accept the existence of a juridical structure worthy of bearing the name of "patrimony" in environmental law, we must study it starting from its components. Even if we

\footnotetext{
${ }^{13}$ François Guy Trébulle, Environnement et droit des biens, vol. "Le droit et l'environnement", Tome XI/Caen, Dalloz, Paris, 2010, p. 85-115, 130.

${ }^{14} \mathrm{M}$. Boutelet, La place de l'action pour trouble de voisinage dans l'évolution du droit de la responsabilité civile en matière de l'environnement, vol. "Cahiers du droit des entreprises", 1999, p. 6

${ }^{15}$ V. Fournel, Traité du voisinage, t.1, 4e, Ed. Tardif, Paris, 1834, p. 24-34.
} 


\section{A. Duţu-Buzura}

are tempted to use concepts consecrated and coming from private law, their specific meanings will differ, considering mainly the particularities of environmental law, and also because we cannot accept that doctrine and terminology are segregated and adhering to certain distinctive units, at least in aspects concerning the concept of patrimony. In such conditions, we are obliged to use terminological loans, but in the same time, we are trying to keep, as much as possible, the first meaning of the terms, adapted, obviously, to the rigors and imperatives of the environmental law problematic.

An environmental patrimony can be an imperfect reflection of the civil law patrimony, a transposition of its traditional characteristics in a field where such a term has been used in an almost improper sense, giving it its well-deserved importance and precision.

As shown earlier, we prefer to use the term environmental patrimony/heritage instead of already consecrated forms, such as natural or common heritage, because the latter two refer to elements of nature, seen as themselves, in their individuality. But "environment" implies the existence of a system within which, between these elements, be they natural or artificial, we encounter interconnections, just as they exist between the environment itself and the human being, in the widest meaning of this notion.

We propose to regard these elements of the environment from a theoretical approach closer to reality, to adopt an ensemble view over the planetary ecosystem, to better emphasize the importance and contribution of each of them to the optimal functioning of the system. In the same time, we would incline to bring an innovative aspect to this patrimony, namely the effects of one element over the other, and the way in which appear and exist interdependency relations, essential to the existence itself of such patrimony.

Even if such considerations did not know a direct juridical expression, they have already been partially overtaken and consecrated, as already shown, by concepts such as common or natural heritage, institutions created by French law at the beginning of the XXth century, imposing a special regime of protection over a certain kind of goods, that needed to be conserved and kept in good state, to the benefit of humanity, hereby including present but also future generations.

With the appearance and emergence of environmental law, these points of view could not limit themselves any more to episodic presences in national regulations or international conventions. Thus, protecting nature has turned, from an almost formal obligation, adjacent to recreational or entertainment needs, into an imperative of the survival of the human species on this planet. As natural resources are characterized, currently, both by scarcity and tenuousness, and in the future a real penury has been foreseen, concerning basic resources as water and soil, a legal regime of protection, both national and international, has become absolutely necessary.

In such conditions, and given the mechanisms already in existence and functioning in this field, we dare to propose the conceptualization and actual creation of an "environmental patrimony", independent from the natural heritage already accepted, to confer to the elements of nature a special legal status, to impose their protection and preservation in satisfactory conditions to their exploitation and capitalization, both for present, but more importantly, for future generations, to determine the strict regulation for this exploitation and, last but not least, to become aware that the only titular or holder of such a patrimony is none other than humanity, as a whole and its most juridical meaning possible.

Given that although it can be limited to natural goods bearing economic value, such a structure must envision also the fact that precisely the economic mechanisms, newly created in this domain, such as exploitation permits for certain resources or pollution certificates, bring a major contribution to consolidating an enforced regime of protection and, in the same time, sustain the fundamental distinction between ecological utility of the environmental good and its economical utility.

Even if such a juridical construct is far from being a reality, we appreciate that, such as the patrimony of civil law has been identified and contoured by Aubry and Rau, starting from 
its functions, the same can happen in environmental law, where, by its special functions of protection and preservation, such an environmental patrimony can be conceptualized.

\section{Conclusions}

This conceptual evolution, from an institution created solely for private purpose, to an instrument of international environmental regulation, has proven itself to be much more than a theoretical attempt to explain the liaison between patrimony, heritage and all other intermediary form of ownership and/or mastery over natural goods. It has become, due to the recent changes and evolutions of perception, an expression of the imperatives and necessities of the "environmental revolution", a tool much needed in view of creating a special legal regime for all goods and resources, in respect to the principles of sustainable development, preservation and protection of the environment and, last but not least, even if it may still sound pretentious, the survival of the human species as a whole.

\section{Bibliography}

François Guy Trébulle, Environnement et droit des biens, vol. "Le droit et l'environnement", Tome XI/Caen, Dalloz, Paris, 2010;

Al. Kiss, J.-P. Beurrier, Droit international de l'environnement, $4 \mathrm{e}$ édition, Pedone, Paris, 2010;

T. Revet, Le Code civil et le régime des biens: questions pour un bicentenaire, rev. "Droit et patrimoine", mars 2004;

D. Hiez, Étude critique de la notion de patrimoine en droit privé actuel, L.G.D.J., Paris, 2003;

P. Byrne, A. Boyle, International law and the environment, second edition, Oxford University Press, 2002;

M. Boutelet, La place de l'action pour trouble de voisinage dans l'évolution du droit de la responsabilité civile en matière de l'environnement, vol. "Cahiers du droit des entreprises", 1999;

E. Zaccai, Générations futures, humanité, nature: difficultés des collectifs pour la protection de l'environnement, vol. "Le droit saisi par le collectif", Ed. Bruylant, Bruxelles, 2004;

Y. Jégouzo, Propriété et environnement, Paris, Defrénois, 1994;

P. Juillard, Rapport français de droit international public, vol. "Travaux de l'Association Henri Capitant", La maitrise du sol, t. XLI, Economica, 1990;

Rémond Gouilloud, Le droit de détruire. Essay sur le droit de l'environnement, PUF, Paris, 1989;

M.-F. Renoux-Zagamé, Origines théologiques du concept moderne de propriété, Libraire Droz, Paris, 1987;

J. Carbonnier, Droit civil. Les biens et les obligations, PUF, Paris, 1984;

T. 175;

Al. Kiss, La notion de patrimoine commun de l'humanité, Rec. cours La Haye, 1982,

G. Morin, Le sens de l'évolution contemporaine du droit de propriété, vol. "Le droit privé français au milieu du XXe siècle. Études offertes à G. Ripert", t. II, LGDJ, 1950;

E. Meynial, Notes sur la formation de la théorie du domaine divisée, vol. "Mélanges Fitting" II, Montpellier, 1908;

Marquis de Vareilles-Sommières, La définition et la notion juridique de proprieté, RTD civ., 1905;

V. Fournel, Traité du voisinage, t.1, 4e, Ed. Tardif, Paris, 1834;

Charles Demolombe, Cours de Code Napoléon, vol. IX, Paris, 1861; 